\title{
Effect of inbreeding on growth and reproduction traits of Beetal goats (short communication)
}

\begin{abstract}
Level of inbreeding and its effects on growth and reproductive traits were measured in Beetal goats using 4554 kidding records (1968-2004) from an experiment station in Pakistan. Level of inbreeding varied over the years; was zero in 1974 then increased $0.42 \%$ per year till 1987 when all the bucks and some of the does were replaced with unrelated animals. From 1988 till 2000, inbreeding again increased $0.21 \%$ per year and declined thereafter due to introduction of unrelated bucks. The average level of inbreeding over the years varied from zero to $7.3 \%$. $42.7 \%$ of all investigated animals were inbred, half of which had inbreeding greater than $6.25 \%$. About $3.4 \%$ of animals were $25 \%$ or more inbred. Regression analysis indicated that birth weight $(p<0.05)$, weaning weight $(\mathrm{p}<0.01)$ and pre-weaning daily gain $(\mathrm{p}<0.01)$ had improved in inbreds while post-weaning daily gain $(\mathrm{p}<0.01)$ deteriorated. Deterioration in weight at first service and at first kidding did not reach statistical significance. Kidding interval increased $(\mathrm{p}<0.01)$ due to inbreeding. Within inbreds, however, decline due to inbreeding was observed for birth, weaning and yearling weight but slopes were not different from zero, statistically. Rate of decline in weight at first service and at first kidding however, was different from zero $(p<0.01)$. Effect of inbreeding on growth and reproductive traits in Beetal goats was not very pronounced in the flock. Planned matings are however, suggested to avoid accumulation of inbreeding and appearance of its deleterious effects.
\end{abstract}

Key Words: inbreeding, growth, reproduction traits, Beetal goat, Pakistan

\section{Zusammenfassung}

Titel der Arbeit: Inzuchteinfluss auf Wachstums- und Fortpflanzungsmerkmale bei Beetal Ziegen (Kurzmitteilung)

Mit Daten aus den Jahren 1968 bis 2004 von 4554 Beetal Ziegenkitzen einer Versuchsstation in Pakistan wurde der Einfluss des Inzuchtniveaus auf deren Wachstums- und Fortpflanzungsmerkmale untersucht. In diesem Zeitraum veränderte sich das Inzuchtniveau. Lag dieses 1974 bei Null so stieg es bis 1987 um jährlich 0,42 \% an, wobei vereinzelt Böcke und einige Muttern durch unverwandte Tiere ersetzt wurden. Von 1988 bis 2000 stieg das Inzuchtniveau jährlich wieder um $0.21 \%$ an um anschließend durch den Einfluss unverwandter Böcke wieder abzunehmen. Im Durchschnitt schwankte der Inzuchtkoeffizient zwischen Null und 7,3 \% wobei $42 \%$ aller in diesem Zeitraum untersuchten Tiere ingezüchtet waren. Für Einzeltiere lag das Inzuchtniveau höher als 41,3 \%. Bei der Hälfte der Inzuchttiere betrug der durchschnittliche Inzuchtkoeffizient mehr als 6,25 \%. Über $3,4 \%$ der Tiere lagen über 25,0 \% Inzucht. Die Regressionsanalyse ergab bei den Inzuchttieren eine Verbesserung beim Geburtsgewicht $(p<0,01)$, dem Absetzgewicht $(p<0,01)$ und der täglichen Zunahme bis zum Absetzen $(p<0,01)$, während die tägliche Zunahme nach dem Absetzen sich verschlechterte. Die Reproduktionsmerkmale waren bis auf die schlechteren Werte beim Geburtsintervall der Inzuchttiere nicht signifkant verschieden. Innerhalb der Inzuchttiere wurden mit steigendem Anteil eine Abnahme bei GeburtsAbsetz- und Jährlingsgewichten beobachtet, die jedoch statistisch nicht signifikant war. Im Vergleich zur Gesamtpopulation unterschieden sich bei den Reproduktionsmerkmalen nur das Bedeckungs- und das Erstgeburtsalter signifikant $(\mathrm{p}<0,001)$ zu Ungunsten der Inzuchttiere. In der untersuchten Herde war der Einfluss der Inzucht auf Wachstum und Fortpflanzung nicht sehr ausgeprägt. Bei der Anpaarungsplanung sollte jedoch ein Anstieg der Inzucht wegen zu erwartender negativer Effekte vermieden werden.

Schlüsselwörter: Inzucht, Wachstumsmerkmale, Fruchtbarkeitsmerkmale, Beetal Ziege, Pakistan 
Introduction

Impaired health, fertility, and productivity of livestock species are generally considered bad impacts of inbreeding. The decisions regarding mating can correct high inbreeding on the farms, at least in the short-term, but long-term control of inbreeding requires consideration of relationships between young males entering the flock (WEIGEL and LIN, 2002). The loss in genetic merit may also occur due to no selection activity. Relationships among selected parents can be reduced substantially but the corresponding reduction in genetic merit may be large (KELLER et al., 1990; WOCAC, 2003). Although, severe restrictions on relationships can be costly, in terms of lost genetic progress, it appears that moderate constraints can keep relationships at a manageable level without a significant loss in genetic merit (BOURDON, 2000). While inbreeding has played a role in development and improvement of specialized strains of livestock, costs clearly outweigh benefits in commercial applications and goats are no exception.

Effect of inbreeding on traits of economic importance is generally accepted similar to that of sheep but studies to document such effects are very limited. MORADISHAHARBABAK et al. (2003) reported that in Raeini cashmere goats, for 6598 birth records, birth weight reduced by 6.1 gram for every $1 \%$ rise in inbreeding in the inbred kids. Weaning weight $(n=3509)$ reduced 24.7 gram while 9-month weight 467 gram. Deterioration was almost double if inbreds had inbred dams. Inbreeding in sheep has been studied extensively. LAMBERSON and THOMAS (1994) reviewed 25 studies on sheep and concluded that inbreeding was detrimental to performance. For each $1 \%$ rise in inbreeding, birth weight decreased by 13 gram and weaning weight by 72 gram but ewe fertility (ewes lambing per ewes joined) and lab survival (labs weaned per lambs born) were the most affected traits. Ewe fertility and lamb survival declined by 0.014 and 0.028 , respectively. It was indicated that selection could not overcome the negative effects of inbreeding when both were practiced simultaneously, due mainly to low reproductive rates in the inbred lines.

KALLWEIT and BAULAIN (2001) found no relationship between inbreeding coefficient and prolificacy in a Finnsheep population during a 34-year period. The effect of inbreeding in sheep races in Pakistan show for example reports of AKHTAR (1986), ALI (1990), MIRZA (1996), KHAN et al. (1995) and AKHTAR et al. (2003). In Pakistan the effect of inbreeding has not been documented in goats, the assumption is that it may have similar effect. For the present flock, deterioration in performance over the years was assumed at least to some extent due to inbreeding and therefore does and bucks have been replaced at least twice since its inception in 1968. The birth weight, weaning weight, yearling weight and efficiency of gains both pre- and postweaning are generally accepted measures of growth while the age and weight at service, age and weight at kidding, service per conception and kidding interval are some of the traits determining the efficiency of reproduction. Measurement of the effect of inbreeding on these traits is important in order to estimate the magnitude of change associated with increases in inbreeding. The objective of the present study was to evaluate pedigree structure of a Beetal flock for estimating inbreeding and its influence on growth and reproductive traits. 
Materials and methods

Pedigree and performance data of a Beetal flock maintained at the Livestock Experiment Station, Rakh Khairewala, (District Layyah), Pakistan, from 1968-2004 were collected for the present study. The station was established in 1962. It is situated in Punjab province about $305 \mathrm{~km}$ in south-west of Lahore. The main objective of the farm was to conserve and improve breeds of the area including Dera Din Pannah, Nachi and Beetal. It was also aimed at producing pedigreed bucks for improving goat breeds in the area. The soil of the area is sandy and about $3 / 4^{\text {th }}$ of the farm area has sand dunes. The plan land is used for growing supplementary fodder. The rainfall is about $100 \mathrm{~mm}$ per year, mainly during July-September. In summer, day temperature may go as high as $55^{\circ} \mathrm{C}$ while winter nights may have temperature as low as $-4^{\circ} \mathrm{C}$.

The flock has generally been closed for outside breeding with the exception of introduction of 245 does in 1974 and 54 does in 1987. Bucks were also replaced in 2000. Since the inception of the Beetal flock in 1968, the does have been selected from and amongst the farm produced female stock primarily on the basis of conformation and breed characteristics. In general, bucks were also selected on the basis of their conformation and breed characteristics with some emphasis to body size. Apparently no selection on growth or other parameters have been carried out. Normally 4-6 bucks per season were selected and used for breeding purposes in the flock.

\section{Statistical analysis}

Pedigree and performance information on 4549 goats were available for the study. Pedigrees were traced back to the base population of 1968. There were file had 4597 animals in total. Inbreeding coefficients were calculated and effect of inbreeding performance traits was studies using a two-tailed t-test comparing inbred and outbred populations. The inbreeding depression in various traits was estimated using linear regression technique (SOKAL and ROHLF, 1995). Traits included growth (birth, weaning and yearling weights along with pre-and post-weaning growth rates) and reproductive traits (age and weight at first service and at first kidding, services per conception and kidding interval). Inbreeding coefficients were calculated with the help of Pedigree software (SARGOLZAEI, 2004).

\section{Results}

Analysis of pedigree records revealed that out of 4597 animals, 1966 (42.7\%) were inbred (Table 1), half of which had inbreeding greater than 6.25\%.The average inbreeding coefficient was 3.7\%. There were 41 animals with inbreeding of more than 25\% percent. About 9.1\% animals were result of matings where mates had full-sib or more strong relationship.

Table 1

Distribution of animals with respect to level of inbreeding (Verteilung des Tiermaterials unter Berücksichtigung von Inzucht)

\begin{tabular}{lcc}
\hline Level of inbreeding (percent) & No. of animals & Percentage \\
\hline Non-inbred & 2633 & 57.3 \\
Up to 6.25 & 971 & 21.1 \\
$>6.25$ to 12.50 & 578 & 12.6 \\
12.50 to 25.00 & 374 & 8.1 \\
$>25.00$ & 41 & 0.9 \\
Overall inbreds & 1966 & 42.7 \\
\hline
\end{tabular}


Level of inbreeding varied across different years was zero in 1974 from where it increased $0.42 \%$ per year till 1987 when most of the bucks and some of the does were replaced with unrelated animals (Figure). From 1988 till 2000, inbreeding again increased $0.21 \%$ per year and declined thereafter due to introduction of unrelated bucks. The average level of inbreeding over the years varied from zero to $7.3 \%$. For individual animals, level of inbreeding was as high as $41.3 \%$. The proportion of inbreds during different years ranged from as low as zero to 88.6\% in 1993 (Figure).

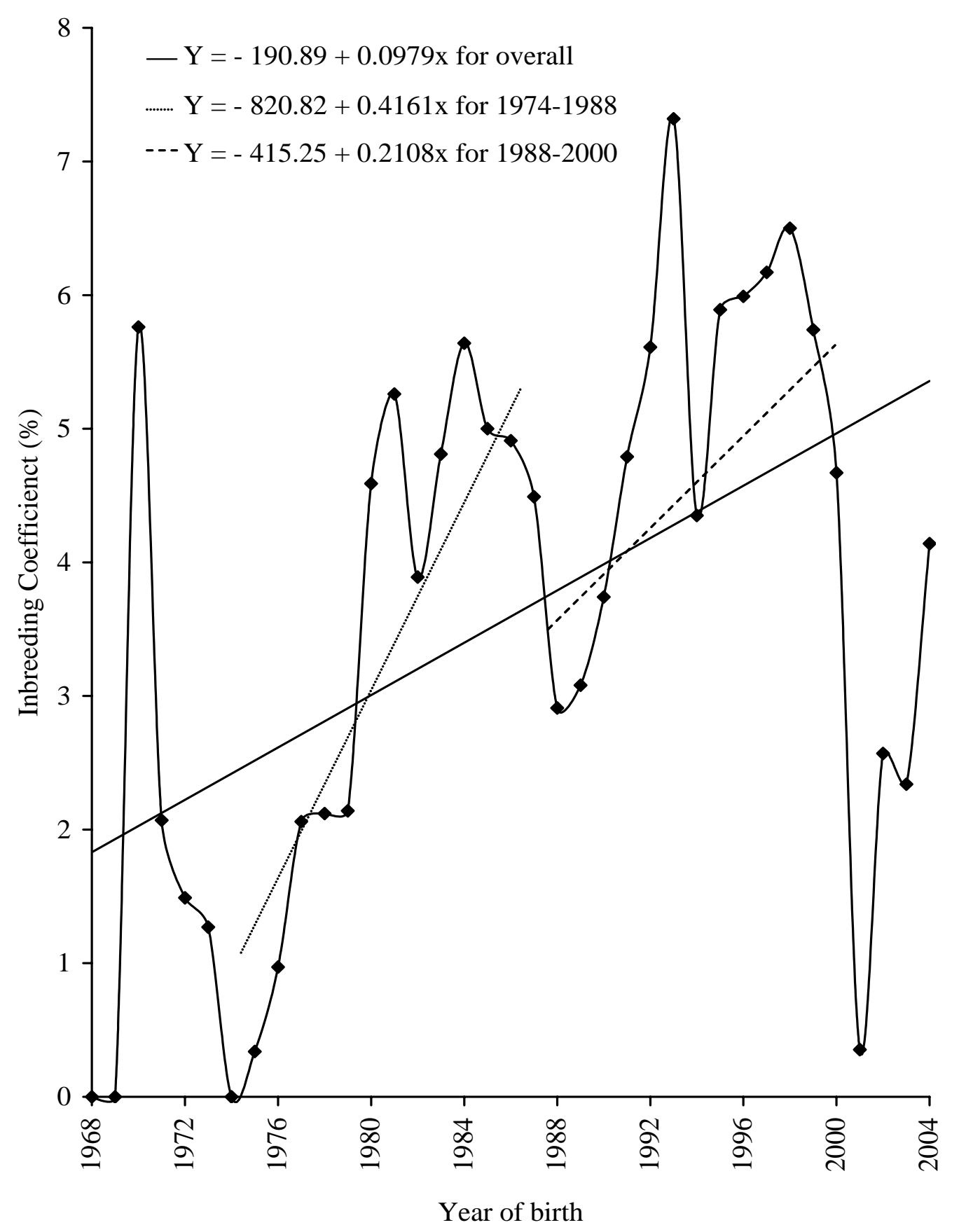

Figure: Inbreeding coefficient of Beetal goats born in different years (Inzuchtkoeffizient von Beetal Ziegen der einzelnen Geburtsjahrgänge)

Birth weight, weaning weight and pre-weaning daily gain were statistically better in inbreds as compared to non-inbreds $(3.2 \pm 0.02$ vs. $3.1 \pm 0.01 \mathrm{~kg}, 15.7 \pm 0.08$ vs. 
$15.0 \pm 0.07 \mathrm{~kg}$ and $105 \pm 0.62$ vs. $99 \pm 0.57 \mathrm{~g}$ ) while post-weaning daily gain was inferior in inbreds as compared to non-inbreds (50 $\pm 0.26 \mathrm{~g}$ vs $52 \pm 0.26 \mathrm{~g}$ vs.). The yearling weight was similar in both the groups. Among the reproductive traits, services per conceptions were slightly better in inbreds $(1.07 \pm 0.28)$ as compared to non-inbreds $(1.11 \pm 0.01)$ but kidding interval was longer in inbreds $(400 \pm 4.32$ days) as compared to non-inbreds (367 \pm 2.81 days). Both the groups had similar means for age and weight at first service and at kidding (Table 2).

Table 2

Comparative performance of non-inbred and inbred Beetal goats (Vergleichende Leistungen bei In- und NichtInzuchttieren)

\begin{tabular}{|c|c|c|c|c|c|}
\hline \multirow{2}{*}{ Traits } & \multicolumn{2}{|c|}{ Non-inbred } & \multicolumn{2}{|r|}{ Inbreds } & \multirow{2}{*}{ |t-statistic| } \\
\hline & $\mathrm{N}$ & Mean \pm SE & $\mathrm{N}$ & Mean \pm SE & \\
\hline \multicolumn{6}{|l|}{ Growth traits } \\
\hline Birth weight (kg) & 2624 & $3.1 \pm 0.01$ & 1930 & $3.2 \pm 0.02$ & $4.47^{* *}$ \\
\hline Weaning weight (kg) & 2320 & $15.0 \pm 0.07$ & 1844 & $15.7 \pm 0.08$ & $6.74^{* *}$ \\
\hline Yearling weight (kg) & 2107 & $28.0 \pm 0.08$ & 1715 & $27.9 \pm 0.09$ & $0.22^{\mathrm{NS}}$ \\
\hline Pre-weaning daily gain (g) & 2323 & $99 \pm 0.57$ & 1846 & $105 \pm 0.62$ & $6.10^{* *}$ \\
\hline Post-weaning daily gain (g) & 2107 & $52 \pm 0.26$ & 1715 & $50 \pm 0.26$ & $7.60^{* *}$ \\
\hline \multicolumn{6}{|l|}{ Reproductive traits } \\
\hline Age at first service (days) & 840 & $750 \pm 8.5$ & 484 & $746 \pm 10.9$ & $0.343^{\mathrm{NS}}$ \\
\hline Weight at first service (kg) & 840 & $34.1 \pm 0.16$ & 484 & $34.2 \pm 0.19$ & $0.089^{\mathrm{NS}}$ \\
\hline Age at first kidding (days) & 924 & $902 \pm 7.8$ & 488 & $894 \pm 10.7$ & $0.559^{\mathrm{NS}}$ \\
\hline Weight at first kidding (kg) & 924 & $43.8 \pm 0.20$ & 488 & $43.7 \pm 0.22$ & $0.163^{\mathrm{NS}}$ \\
\hline Services per conception & 3777 & $1.11 \pm 0.00$ & 1812 & $1.07 \pm 0.28$ & $4.58^{* *}$ \\
\hline Kidding interval (days) & 1910 & $367 \pm 2.81$ & 915 & $400 \pm 4.32$ & $6.39^{* *}$ \\
\hline
\end{tabular}

**: $\mathrm{p}<.01 ; *$ : $\mathrm{p}<.05$; NS: Non-significant

The inbreeding depression was estimated using all the records (Table 3) and slopes were $0.0004 \mathrm{~kg}, 0.0028 \mathrm{~kg},-0003 \mathrm{~kg}, 0.2020$ gram and -0.1130 gram for birth weight, weaning weight, yearling weight, pre-weaning growth rate and post-weaning growth rate, respectively. Depression of post-weaning daily gain $(-0.113 \mathrm{~g})$ was statistically significant $(\mathrm{p}<.01)$. Among the reproductive traits, depression/ deterioration was observed for kidding interval only where it had increased @ 1.696 days per one percent increase in inbreeding.

Table 3

Effect of inbreeding* on various performance traits of Beetal goats (Einfluss der Inzucht auf verschiedene Leistungsmerkmale bei Beetal Ziegen)

\begin{tabular}{|c|c|c|c|c|c|c|}
\hline \multirow[b]{2}{*}{ Traits } & \multicolumn{3}{|c|}{ All population } & \multicolumn{3}{|c|}{ Inbred population } \\
\hline & $\alpha$ & $\beta$ & Prob. & $\alpha$ & $\beta$ & Prob. \\
\hline \multicolumn{7}{|l|}{ Growth traits } \\
\hline Birth weight (kg) & 3.1 & 0.00038 & 0.022 & 3.2 & -0.00031 & 0.182 \\
\hline Weaning weight (kg) & 15.2 & 0.00283 & 0.001 & 15.9 & -0.0021 & 0.072 \\
\hline Yearling weight (kg) & 28.0 & -0.00031 & 0.746 & 28.0 & -0.00055 & 0.668 \\
\hline Pre-weaning daily gain (g) & 101 & 0.202 & 0.003 & 106 & -0.157 & 0.084 \\
\hline Post-weaning daily gain (g) & 52 & -0.113 & 0.000 & 49 & 0.00707 & 0.061 \\
\hline \multicolumn{7}{|l|}{ Reproductive traits } \\
\hline Age at first service (days) & 752 & -0.871 & 0.422 & 757 & -1.217 & 0.421 \\
\hline Weight at first service (kg) & 34.2 & -0.0033 & 0.096 & 34.8 & -0.0068 & 0.006 \\
\hline Age at first kidding (days) & 903 & -1.127 & 0.278 & 908 & -1.447 & 0.328 \\
\hline Weight at first kidding (kg) & 43.9 & -0.0045 & 0.069 & 44.5 & -0.0085 & 0.006 \\
\hline Services per conception & 1.2 & -0.0041 & 0.000 & 1.1 & -0.00013 & 0.888 \\
\hline Kidding interval (days) & 373 & 1.696 & 0.000 & 403 & -0.389 & 0.528 \\
\hline
\end{tabular}

\footnotetext{
"change in the trait per percent change in inbreeding in terms of intercept $(\alpha)$, slope $(\beta)$ and probability that slope is different from zero.
} 
Restricting data to inbred population, gave slightly different results (Table 3). Depression in post-weaning daily gain was not important statistically, any more. Among the reproductive traits, depression in kidding interval did not reach statistical significance but weight at first service declined by $0.0068 \mathrm{~kg}$ and weight at first kidding by $0.0085 \mathrm{~kg}$ with each percent increase in inbreeding and both the slopes were different from zero $(\mathrm{p}<0.01)$. The trends were also compared for the two periods (1974-1987 and 1988-2000) when the level of inbreeding increased (Figure) after the initial introduction of unrelated bucks and does but it did not change conclusions. Replacement of bucks in 2000 decreased inbreeding in the subsequent years as indicated in the Figure.

\section{Discussion}

Although non-random mating of bucks was the primary reason for choosing the phenotypes instead of generating meaningful BLUPS but detailed study (not part of this short communication) indicated that genetic trends in most traits were close to zero and therefore phenotypes were chosen instead of BLUP estimates to report the effect of inbreeding. Also, it was easy to explain deterioration in a trait rather that breeding value at farmer level.

Inbreeding is generally associated with deterioration in growth in reproductive traits in small ruminants (LAMBERSON and THOMAS, 1994; WOCAC, 2003) and level of inbreeding may be an important factor for such effects to appear. Although, some of the animals in the present flock were highly inbred, level of inbreeding was generally low (3.7\%), mainly due to periodic introduction of unrelated does and bucks which helped in checking the rate of increase in the level of inbreeding. Although, some of the animals introduced may be relatives, but were assumed unrelated because of lack of pedigree recording at filed level from where such animals were purchased. This may be one of the factors that resulted in estimation of low level of inbreeding in the present flock. With the exception of few years, most of the animals were always inbred across different years (Figure), level of inbreeding was low. The inbreeding may accumulate quickly for a flock of this size due mainly to small effective population size as indicted by ILKIN (1979) where inbreeding increased to 28 percent over a period of about 15 years in a flock of British Alpine goats. Survival data and prolificacy data were missing for some of the years and were not used for the present study; information on the effect of inbreeding would have been otherwise more complete. Increasing number of breeding males for each breeding season would help to improve the effective population size.

The level of inbreeding was comparatively low in the flock under study, due mainly to twice introduction of unrelated does and bucks during the study period. Some of the traits such as yearling weight and kidding interval did show deterioration due to inbreeding while some improvement was seen due to inbreeding in birth and weaning weight. The continuous rise in the level of inbreeding over the years however, warns that matings in the future should be more planned to avoid matings of close relatives. Increase in number of breeding males and their more frequent replacement would help reduce the level of inbreeding. 
AKHTAR, M.:

\section{References}

Studies on the performance of Awassi sheep in Pakistan III. Effect of inbreeding on different traits. M. Sc. Thesis, Department of Animal Breeding and Genetics, University of Agriculture Faisalabad, Pakistan (1986)

AKHTAR, P.; KHAN, M. S.; MOHIUDDIN, G.; ABDULLAH, M.:

Effect of inbreeding on some performance traits of Hissardale sheep in Pakistan. Pakistan Vet. J. 20 (1003), 169-172

ALI, A.:

Effect of inbreeding on reproductive traits of Awassi sheep in Pakistan. M. Sc. Thesis, Department of Animal Breeding and Genetics, University of Agriculture Faisalabad, Pakistan (1990)

BOURDON, R. M.:

Understanding Animal Breeding. Prentice Hall, New Jersey (2000)

ILKIN, T. L.:

Genetic analysis of the British Alpine goat flock in Australia. In: Proc. $2^{\text {nd }}$ National Goat Breeders

Conference, Perth, Australia. (1979), 125-130 (Anim. Breed. Abstr. 49 (1981), 2050)

Breeding and Genetics, University of Agriculture Faisalabad, Pakistan (1984)

KALLWEIT, E.; BAULAIN, U.:

Reproduction performance and degree of inbreeding in a small Finnsheep population during a 34-year period. Arch. Tierz., Dummerstorf 44 (2001) Special Issue, 263-270

KELLER, D. S.; GEARHEART, W. W.; SMITH, C.:

A comparison of factors reducing selection response in closed nucleus breeding schemes. J. Anim. Sci. 68 (1990), 1553-1561

KHAN, M. S.; AHMAD, M. D.; AHMAD, Z.; JADOON, J. K.:

Effect of inbreeding on performance traits of Rambouillet sheep. J. Anim. Plant Sci. 5 (1995), 13-14

LAMBERSON, W. R.; THOMAS, D. L.:

MIRZA, R. H.:

Effects of inbreeding in sheep: a review. Anim. Breed. Abstr. 52 (1984), 287-297

Effect of inbreeding on productive and reproductive traits in Lohi sheep. M. Sc. Thesis, Department of Animal Breeding and Genetics, University of Agriculture Faisalabad, Pakistan (1996)

MORADI-SHAHARBABAK, M.; MOHAMMADI, A.; MIRAEI-ASHTIANI, S. R.:

Inbreeding and its effects on some economic traits in Raeini cashmere goats. (2003) www.bsas.org.uk/downloads/annlproc/Pdf2003/147.pdf.

SARGOLZAEI, M.:

User's manual of Pedigree version 1.02. Department of Animal Breeding and Genetics, Animal Science Research Institute, Karaj, Iran (2004)

SOKAL, R. R.; ROHLF, F. J.:

Biometry. The Principles and Practice of Statistics in Biological Research ( $3^{\text {rd }}$ Ed). W. H. Freeman \& Co. USA (1995)

WEIGEL, K. A.; LIN, S. W.:

Controlling inbreeding by constraining the average relationship between parents of young bulls entering AI progeny test programs Journal of Dairy Science 85 (2002), 2376-2383

WOCAC, R.M.:

On the importance of inbreeding at Tauernschecken goats (German language). Arch. Tierz., Dummerstorf 46 (2003), 455-469

Received: 2006-01-27

Accepted: 2006-11-23

Author's address

M. SAJJAD KHAN*, AFZAL ALI, ASAD ULLAH HYDER, AMJAD IQBAL CHATTA

Department of Animal Breeding and Genetics, University of Agriculture and

Livestock Experiment Station Khairewala, District Layyah,

FAISALABAD 38040, PAKISTAN

*Corresponding Author

E-Mail: drsajjad2@yahoo.com 